\title{
Dermatology
}

Dermatology 2009;219:359-360

DOI: $10.1159 / 000243806$

\section{Successful Response to Topical Tacrolimus for a Granuloma Faciale in an Elderly Patient}

\author{
Nuria Pérez-Robayna, Cristina Rodríguez-García, \\ Sorahaya González-Hernández, Rosalba Sánchez, \\ Francisco Guimerá, Miguel Sáez
}

Department of Dermatology, Hospital Universitario de Canarias, University of La Laguna, La Laguna, Tenerife, Spain

Key Words

Granuloma, face $\cdot$ Tacrolimus $\cdot$ Aged subjects

Granuloma faciale (GF) is an uncommon cutaneous disease which presents most often in middle-aged patients. Although its etiology is still unclear, many reports suggest that GF is a local form of cutaneous vasculitis. Many facts suggest that GF and erythema elevatum diutinum may be produced by a similar or the same pathogenic mechanism. For example, both are chronic localized forms of cutaneous leukocytoclastic vasculitis that result in patterned fibrosis. However, erythema elevatum diutinum often occurs in systemically ill patients as bilaterally symmetrical plaques, papules or nodules over the dorsa of joints, and GF usually appears as one or a few plaques on the face. In addition, eosinophils and plasma cells are prominent in GF, whereas neutrophils are plentiful in erythema elevatum diutinum [1]. GF is often quite resistant to therapy [2-6]. Topical calcineurin inhibitors may represent a useful alternative to topical corticosteroids for the treatment of a number of other inflammatory skin diseases different from atopic dermatitis [7].

We report a 90 -year-old male patient without remarkable medical history who presented to our department with an asymptomatic lesion on the nasal tip. This lesion had been present for 6 months, and gradual enlargement had been observed.

Physical examination revealed an oval, well-delimited, reddish yellow plaque, $2.5 \times 1.5 \mathrm{~cm}$ in size, with a smooth and brilliant surface. Focal telangiectasia and follicular openings were also found (fig. 1). A biopsy specimen was obtained which showed a dense dermal polymorphous inflammatory infiltrate with neutrophils, lymphocytes, plasma cells and numerous eosinophils. A narrow grenz zone and a mild fibrosis area were also found. With these histological findings, a diagnosis of GF was made.

Therapy with topical $0.1 \%$ tacrolimus ointment twice daily was started after he had not responded to the application of topical corticosteroids. Treatment was stopped after 3 months with remission lasting for 1 year. Only slight reddish coloration at the edges of the lesion remained (fig. 2). No burning sensation was noted.

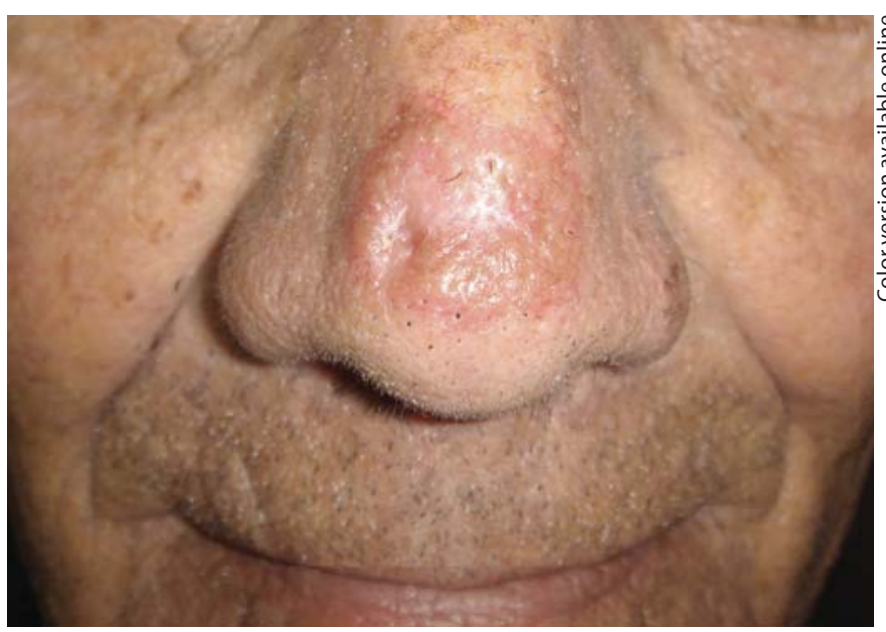

Fig. 1. Reddish yellow plaque at the tip of the nose.

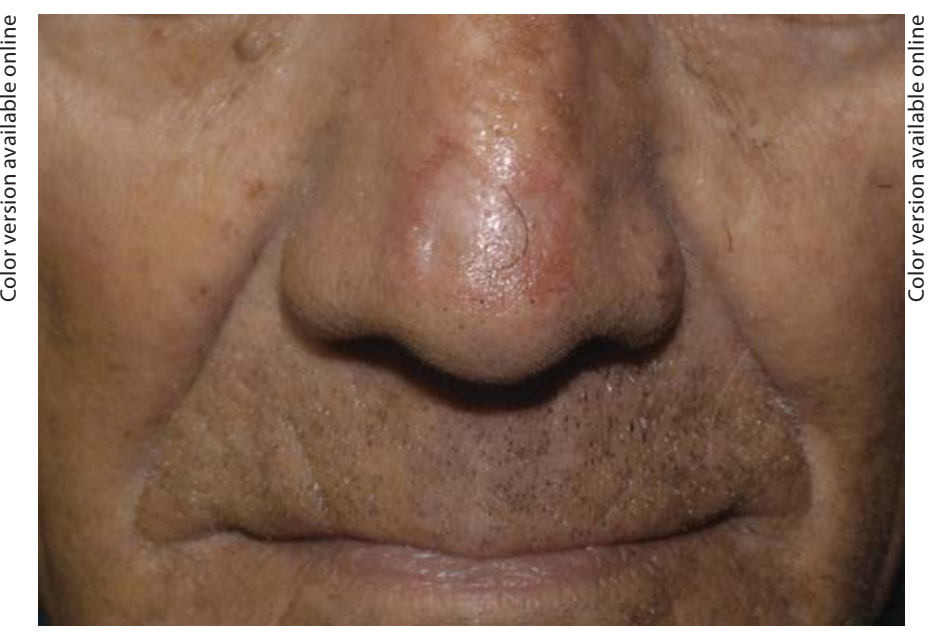

Fig. 2. After therapy, only slightly colored edges of the lesion remain.

\section{KARGER}

\section{(C) 2009 S. Karger AG, Basel}

Fax +41613061234 E-Mail karger@karger.ch www.karger.com 
Table 1. Previously reported experiences with topical calcineurin inhibitors for GF

\begin{tabular}{|c|c|c|c|c|c|c|}
\hline Authors & Sex & $\begin{array}{l}\text { Age } \\
\text { years }\end{array}$ & Location & Previous treatment & Prescribed treatment & Evolution \\
\hline $\begin{array}{l}\text { Tomson et al. } \\
{[2], 2009}\end{array}$ & male & 50 & cheeks & $\begin{array}{l}\text { oxytetracycline, } \\
\text { cryotherapy }\end{array}$ & $\begin{array}{l}\text { topical tacrolimus } 0.1 \% \\
\text { twice daily, } 1 \text { year }\end{array}$ & $\begin{array}{l}\text { lesions reappeared, topi- } \\
\text { cal tacrolimus again }\end{array}$ \\
\hline $\begin{array}{l}\text { Tomson et al. } \\
{[2], 2009}\end{array}$ & male & 65 & cheeks and forehead & $\begin{array}{l}\text { mometasone } \\
\text { furoate } 0.1 \% \text { cream }\end{array}$ & $\begin{array}{l}\text { topical tacrolimus } 0.03 \% \\
\text { twice daily, } 6 \text { months }\end{array}$ & no recurrence \\
\hline $\begin{array}{l}\text { Jedlicková } \\
\text { et al. [11], } 2008\end{array}$ & male & 60 & unknown & $\begin{array}{l}\text { topical costicosteroids, } \\
\text { cryotherapy }\end{array}$ & $\begin{array}{l}\text { topical tacrolimus } 0.1 \% \\
\text { twice daily, } 4 \text { months }\end{array}$ & no recurrence \\
\hline $\begin{array}{l}\text { Marcoval } \\
\text { et al. [4], } 2006\end{array}$ & male & 64 & $\begin{array}{l}\text { forehead and } \\
\text { preauricular }\end{array}$ & topical corticosteroids & $\begin{array}{l}\text { topical tacrolimus } 0.1 \% \\
\text { twice daily, } 2 \text { months }\end{array}$ & $\begin{array}{l}\text { almost completely } \\
\text { disappeared }\end{array}$ \\
\hline $\begin{array}{l}\text { Eetam et al. } \\
{[12], 2006}\end{array}$ & female & 41 & $\begin{array}{l}\text { nasal dorsum and } \\
\text { left malar region }\end{array}$ & none & $\begin{array}{l}\text { topical pimecrolimus } 1 \% \\
\text { twice daily, } 2 \text { months }\end{array}$ & resolved \\
\hline $\begin{array}{l}\text { Mitchell [6], } \\
2004\end{array}$ & male & 59 & cheeks & $\begin{array}{l}\text { excision, intralesional } \\
\text { costicosteroids }\end{array}$ & $\begin{array}{l}\text { topical tacrolimus } 0.1 \% \text {, } \\
10 \text { months }\end{array}$ & resolved \\
\hline $\begin{array}{l}\text { Ludwig et al. } \\
{[3], 2003}\end{array}$ & female & 64 & $\begin{array}{l}\text { forehead, cheeks } \\
\text { and nose }\end{array}$ & none & $\begin{array}{l}\text { topical tacrolimus } 0.1 \% \\
\text { twice daily, } 6 \text { months }\end{array}$ & $\begin{array}{l}\text { most of the lesions } \\
\text { resolved }\end{array}$ \\
\hline
\end{tabular}

Because of the prominent location of GF on the face, treatment is often desired [3]. Therefore, topical, intralesional and systemic corticosteroids, electrosurgery, cryotherapy, diverse modalities of laser, dapsone, clofazimine, colchicine, PUVA therapy, dermabrasion or surgical excision have previously been applied with different responses [2-4]. In addition, topical calcineurin inhibitors have been shown to be effective in several inflammatory diseases $[3,7]$ such as pemphigus foliaceus, discoid lupus erythematosus, granulomatous periorificial dermatitis [8], erosive pustular dermatosis of the scalp [9] and even in other rare conditions such as cutaneous plasmocytosis [10]. So, encouraged by previous successful experiences with topical tacrolimus in GF (table 1), we started this treatment in our patient with a good therapeutic response.

Immunophenotypic molecular analysis of the dermal infiltrate in GF reveals that most lymphocytes are clonally expanded, memory T-helper CD4+ cells. Futhermore, it is suggested that the accumulation of the inflammatory infiltrate in GF lesions is mediated by $\gamma$-interferon. Tacrolimus acts by binding and inactivating calcineurin, so T-cell activation and proliferation are blocked. As a result, secretion of $\gamma$-interferon is inhibited [2]. In addition, a decrease in interleukin 5 production by topical tacrolimus may lead to a reduction of the number of eosinophils present in the lesions [4]. In contrast to topical corticosteroids, skin atrophy is not observed after long-term treatment with topical calcineurin inhibitors [3]. In conclusion, the approach to use topical tacrolimus appears to be reasonable in the management of this condition. We would like to point out the presentation of GF in an elderly population and the effective and well-tolerated therapeutic response in our patient. Finally, we suggest that topical tacrolimus could be an effective and safe treatment option for GF.

\section{References}

1 Carlson JA, Le Boit PE: Localized chronic fibrosing vasculitis of the skin: an inflammatory reaction that occurs in settings other than erythema elevatum diutinum and granuloma faciale. Am J Surg Pathol 1997:21:698-705.

- 2 Tomson N, Sterling JC, Salvary I: Granuloma faciale treated successfully with topical tacrolimus. Clin Exp Dermatol 2009;34:424-425.

-3 Ludwig E, Allam JP, Bieber T, Novak N: New treatment modalities for granuloma faciale. Br J Dermatol 2003;149:634-637.

4 Marcoval J, Moreno A, Bordas X, Peyrí J: Granuloma faciale: treatment with topical tacrolimus. J Am Acad Dermatol 2006;55:S110-S111.

-5 Ortonne N, Wechsler J, Bagot M, Grosshans E, Cribier B: Granuloma faciale: A clinicopathologic study of 66 patients. J Am Acad Dermatol 2005;53:1002-1009.

6 Mitchell D: Successful treatment of granuloma faciale with tacrolimus. Dermatol Online J 2004;10:23.

7 Luger T, Paul C: Potential new indications of topical calcineurin inhibitors. Dermatology 2007;215:45-54.

8 Hussain W, Daly BM: Granulomatous periorificial dermatitis in an 11year-old boy. J Eur Acad Dermatol Venereol 2007;21:137-139.

-9 Tavares-Bello R: Erosive pustular dermatosis of the scalp: a chronic recalcitrant dermatosis developed upon $\mathrm{CO}_{2}$ laser treatment. Dermatology 2009;219:71-72.

10 Hafner C, Hohenleutner U, Babilas P, Landthaler M, Vogt T: Targeting T cells to hit B cells: successful treatment of cutaneous plasmacytosis with topical pimecrolimus. Dermatology 2006;213:163-165.

11 Jedlicková H, Feit J, Semrádová V: Granuloma faciale successfully treated with topical tacrolimus: a case report. Acta Dermatovenerol Alp Panonica Adriat 2008;17:34-36.

12 Eetam I, Ertekin B, Unal I, Alper S: Granuloma faciale: Is it a new indication for pimecrolimus? A case report. J Dermatolog Treat 2006;17:238-240.

Nuria Pérez-Robayna

Department of Dermatology, Hospital Universitario de Canarias University of La Laguna, ES-38320 La Laguna, Tenerife (Spain) Tel. +34 616123 247, Fax +34922632 274

E-Mail nuriarobayna@yahoo.es 